\title{
Does a Foreign Board Improve Corporate Social Responsibility?
}

\author{
Doddy Setiawan ${ }^{1,2, *(\mathbb{D}}$, Rayenda Khresna Brahmana ${ }^{3}$, Andi Asrihapsari ${ }^{1}$ (D) and Siti Maisaroh ${ }^{1}$ (D) \\ 1 Faculty of Economics and Business, Universitas Sebelas Maret, Surakarta 57126, Indonesia; \\ andiasrihapsari@staff.uns.ac.id (A.A.); maisarohs857@student.uns.ac.id (S.M.) \\ 2 Center for Fintech and Banking, Universitas Sebelas Maret, Surakarta 57126, Indonesia \\ 3 College of Business Administration, University of Bahrain, Sakhir 32038, Bahrain; raye_brahm@yahoo.com \\ * Correspondence: doddy.setiawan@staff.uns.ac.id
}

Citation: Setiawan, D.; Brahmana, R.K.; Asrihapsari, A.; Maisaroh, S. Does a Foreign Board Improve Corporate Social Responsibility? Sustainability 2021, 13, 11473. https://doi.org/10.3390/ su132011473

Academic Editors: Thomas J. Walker and Jane McGaughey

Received: 16 September 2021

Accepted: 15 October 2021

Published: 17 October 2021

Publisher's Note: MDPI stays neutral with regard to jurisdictional claims in published maps and institutional affiliations.

Copyright: (c) 2021 by the authors. Licensee MDPI, Basel, Switzerland. This article is an open access article distributed under the terms and conditions of the Creative Commons Attribution (CC BY) license (https:// creativecommons.org/licenses/by/ $4.0 /)$.

\begin{abstract}
This study examines the effect of foreign boards on corporate social responsibility, exploring the issues of two-tier board systems (boards of directors and boards of commissioners). Using data for manufacturing firms listed on the Indonesia Stock Exchange over the sample period of 2017-2019, the results suggest that a foreign board engages more in corporate social responsibility activities. Our key finding remains robust with respect to all foreign board measures (foreign ownership, foreign board members, foreign directors, foreign commissioners, foreign CEO, and foreign chairperson) and to alternative estimation methods, and pass a series of endogeneity checks. We established the causal effect from foreign boards to CSR, supporting institutional theory and contesting agency theory.
\end{abstract}

Keywords: corporate social responsibility; foreign board; foreign directors; foreign commissioners; foreign CEO; foreign chairperson

\section{Introduction}

Corporate social responsibility (CSR) is an important topic that emerges in the business environment [1]. It refers to firm activities that are intended to achieve financial performance along with nonfinancial performance, such as people and planet wellbeing. Given its importance for business and society, it receives extensive discussion in the accounting and business literature, exploring its impact on firm performance [2], earnings quality [3,4], earnings response coefficient [5], tax planning [6], and market competition [7]. One intriguing aspect in this area is the effectiveness of corporate governance [8] -in particular, the managerial characteristics that are important antecedents of corporate social responsibility.

Corporate governance mechanisms, such as control and monitoring, are an important aspect of CSR activities. Proponents of the legitimacy theory argue that agents (managers) will perform proactively in CSR to earn legitimacy in achieving value creation [9]. In other words, this theory posits that managers will pursue more CSR to achieve a better firm position. Conversely, the agency theory suggests that agents may reduce CSR to avoid higher agency costs due to information costs [10]. This means that the agency theory posits that agents will be less likely to pursue CSR activities.

The aforementioned corporate governance mechanisms are embedded in the characteristics of the board because the members of the board play an essential role in strategic choices, such as CSR [11,12]. For instance, Khan et al. [12] and Rustam and Wang [13] have shown the importance of foreign ownership to push companies to engage more in CSR. Bertrand et al. [14] surmise the importance of foreign CEOs on CSR, and Conyon and $\mathrm{Haß}$ [15] find positive effects of foreign directors on CSR. This suggests that foreign boards apply their international experience and exposure to control and monitoring mechanisms, specifically CSR exposure.

The importance of foreign boards in corporate governance mechanisms lacks empirical findings despite its impact on firms. Foreign directors use their expertise to have a positive 
effect on firm value [16], decrease earning management [17,18], increase reputation [16], and reduce tax aggressiveness [19]. Based on this logic, a foreign board may support the legitimacy theory, suggesting that foreign agents pursue more CSR activities. However, this important topic has not received comprehensive direct attention in the CSR literature and is thus poorly understood. The CSR literature is dominated by a single foreign board dimension and does not examine boards in detail.

In short, this study examines the effect of foreign boards on CSR by comparing the legitimacy theory and agency theory. To achieve this objective, we take Indonesia as the research subject for several reasons. First, like other emerging countries, the proportion of foreigners on Indonesian company boards is quite significant. Second, Indonesia has a unique two-tier board system. This allows us to test the effect of board directors and board commissioners separately. Additionally, Indonesia does not allow CEO duality, allowing us to test the foreign effect of CEOs and chairpersons separately. Note that in terms of the segregation of duties, the board of directors is involved in the management duty of the companies, while the board of commissioners has supervisory functions.

The remainder of the paper is structured as follows. Section 2 elaborates our theoretical arguments and formulates our hypotheses. The data and methodology are presented in Section 3, and the results and discussion are in Section 4. The conclusion is given in the final section.

\section{Literature Review and Hypothesis Development}

\subsection{Theoretical Arguments}

A systematic review of corporate social responsibility (CSR) studies by Velte [9] addresses the legitimacy theory and agency theory as the underlying theories explaining CSR activities. From the legitimacy theorist's point of view, agents (managers) follow the best managerial practices (such as CSR) to make the organization more efficient and create value $[12,20,21]$. If agents are more legitimate, they will have more CSR activities. From the perspective of agency theorists, transparency through voluntary disclosure (such as CSR) leads to an agency cost reduction. If agents are more focused on the agency perspective, they will have fewer CSR activities [10].

One aspect to explain this contradictory perspective may be the corporate governance mechanism [21]. An efficient and effective mechanism may lead to different CSR practices [11,12,21]. In particular, ownership structure, board composition, and managerial characteristics can be important determinants of CSR in a company [12,21]. For instance, McGuinness et al. [11] revealed the positive association between foreign ownership and CSR. There is also a positive effect of foreign CEO and CSR activities according to Bertrand and Betschinger [14]. Additionally, Garanina and Aray [21] showed the positive impact of foreign board members on CSR. Given the importance of those characteristics on CSR, understanding how foreign boards influence CSR is critical to enriching the literature, specifically for the debate between legitimacy theory and agency theory.

\subsection{Foreign Ownership and Corporate Social Responsibility}

One of the determinant factors for corporate social responsibility is ownership structure [21]. Owners discretionarily influence firm decisions regarding corporate social responsibility. Foreign owners are more concerned about the quality of corporate governance practice in the company [22]. Foreign investors push companies to apply better corporate governance practices. The company will have better quality corporate governance, and it is expected to improve firm performance. Mishra (2014) conducted a study on the relationship between foreign ownership and firm value using the Australian context. The results of this study confirmed the expectation that foreign ownership provides additional evidence of firm value.

Foreign ownership also has a positive effect on other discretionary aspects, such as foreign ownership pushing companies to pay more dividends [23]. Foreign owners align their interest with shareholders; therefore, foreign ownership prefers better trans- 
parency [24] and earnings quality [25]. Foreign owners also give more attention to the firm's activities on corporate social responsibility. Rustam et al. [13] analyzed the impact of foreign ownership on corporate social responsibility using the Pakistan context. The results of their study show that foreign ownership has a significant relationship to positive corporate social responsibility improvement. Foreign owners use their discretion to push companies to be more involved in corporate social responsibility activities. The results of Rustam et al. [13] confirm previous studies, such as Khan et al. [12] and Hu and Zhu [26], who found a positive impact of foreign ownership on improving corporate social responsibility in Bangladesh and China, respectively. However, the effect of foreign ownership is weakened in Chinese state-owned enterprises.

On the other hand, Garanina and Aray [21] investigated the effect of foreign ownership on corporate social responsibility performance using the Russian context. The results of their study show that foreign ownership has a negative effect on corporate social responsibility. Foreign owners have fewer incentives to improve corporate social responsibility in Russia. Further analysis shows that most foreign ownership in Russia is mostly from non-Western countries; therefore, they do not fully absorb corporate social responsibility behavior. This study is also in line with McGuinness et al. [11], who found that the level of foreign ownership has a negative effect on corporate social responsibility in China. Furthermore, Al-Gamrh and Al-Dhamari [27] also found that foreign ownership decreases corporate social responsibility performance in the UAE. However, Gulzar and Cherian [28] did not find a significant effect of foreign ownership on corporate social responsibility in China. Foreign ownership in China has fewer incentives to push companies to be more involved in corporate social responsibility.

The presence of foreign ownership is expected to give more benefit to companies, such as improving corporate governance practice [22,24] and firm value [29], as indicated by paying more dividends [23] and having higher earnings quality [25]. Foreign ownership has discretion to push companies to give more attention to corporate social responsibility in home companies. Therefore, foreign ownership has a positive effect on social responsibility $[12,13,26]$. It is expected that foreign ownership positively improves corporate social responsibility. Thus, our first hypothesis is:

\section{Hypothesis 1. Foreign ownership has a positive effect on corporate social responsibility.}

\subsection{Foreign Board and Corporate Social Responsibility}

The article by Oxelheim and Randøy [16] provides evidence that the willingness of a company to add foreign nationals to their board is a signal that the firm is ready to improve its transparency and corporate governance practices. Foreign directors are expected to provide value added to the company, such as improving the monitoring function. A previous study by Gianetti and Liao [30] investigated the effect of Chinese companies' decisions to bring directors with foreign experience to give value added to the company. The results of the study show that foreign directors transfer their knowledge and experience regarding best practices in management and corporate governance. This transfer leads to better firm performance. It will have an impact on reducing earnings management [17,18], reducing tax aggressiveness [19], and improving earnings information sharing [31]. Thus, foreign boards are also expected to have a positive effect on corporate social responsibility activities.

Garanina and Aray [21] investigated the impact of foreign boards on corporate social responsibility at Russian companies, finding that foreign boards positively affect corporate social responsibility in Russian companies. This result shows that foreign directors use their expertise to push companies to engage more in corporate social responsibility. Foreign directors provide added value to Russian companies by increasing long-term stakeholders [21]. Similar evidence is provided by Rustam et al. [13], who found that the presence of foreign directors in French companies increases the environmental performance and community development aspect of corporate social responsibility. Foreign directors are 
able to drive management to pay more attention to environmental aspects and community involvement. A previous study also shows that foreign directors have a positive impact on corporate social responsibility in Jordan [32] and Bangladesh [33].

On the other hand, Colakoglu and Eryilmaz [34] conducted a study regarding the diversity on the board and corporate social responsibility performance in Turkey. Their study included the 500 largest firms in Turkey. The results of their study found no effect of foreign directors on corporate social responsibility performance in Turkey. Foreign directors might not have a significant effect on company decisions regarding corporate social responsibility. Furthermore, Majeed and Aziz [35] tested the effect of foreign directors on the corporate social responsibility performance of Pakistan companies. The results of their study found evidence contrary to expectations. Foreign directors in Pakistan negatively affect corporate social responsibility in Pakistan. Thus, Colakoglu et al. [34] and Majeed et al. [35] provide no evidence of the positive effect of foreign directors on corporate social responsibility.

Foreign directors on a board provide their expertise and experience to board processes and decisions. It is expected that foreign directors add positive value to the company [16,30]. Foreign directors use their expertise to push companies to be more involved in corporate social responsibility activities. Thus, it is expected that foreign boards have a positive effect on corporate social responsibility.

Hypothesis 2. Foreign boards have a positive effect on corporate social responsibility; a higher proportion of foreign members on boards increases the corporate social responsibility of a firm.

Indonesia uses two-tier board systems that consist of boards of directors and boards of commissioners. Therefore, the next hypothesis expects that foreign nationality on the boards of directors and foreign CEOs would have a positive effect.

Hypothesis 3. Foreign directors have a positive effect on corporate social responsibility; a higher portion of foreign directors on the board of directors increases the corporate social responsibility of a firm.

Hypothesis 4. A foreign CEO has a positive effect on corporate social responsibility; a firm with a foreign CEO outperforms the CSR of a firm without a foreign chairperson.

Regarding the role of foreign nationals on boards of commissioners, this study also expects that foreign commissioners and a foreign chairperson on a board of commissioners (a foreign chairperson) would have a positive effect on corporate social responsibility.

Hypothesis 5. Foreign commissioners have a positive effect on corporate social responsibility; a higher portion of foreign commissioners on the board of commissioners increases the corporate social responsibility of a firm.

Hypothesis 6. A foreign chairperson has a positive effect on corporate social responsibility; a firm with a foreign chairperson outperforms the CSR of a firm without a foreign chairperson.

\section{Research Methodology}

\subsection{Data}

The initial firms of the study are listed on the Indonesia Stock Exchange. Furthermore, the study focuses on the manufacturing industry in Indonesia during the 2017-2019 period. There are 495 firm-year observations as the sample of the study. We collected the information regarding the annual report from the Indonesian Stock Exchange. To review the nationality of foreign directors and foreign boards, we reviewed the biographies of each director and commissioner in their annual reports. We also hand-collected biographical information about the directors from Bloomberg. 


\subsection{Specification of Model}

The legitimacy theory suggests that firm characteristics are important factors in pursuing CSR. To accommodate this proposition of that theory, we used prior empirical research, such as Garanina and Aray [21], which addresses several determinants to explain the function of CSR, such as firm size (SIZE), firm leverage (LEVERAGE), firm profitability (ROA), and Big Four audit firms (AUDIT). We added gender and firm age as two additional control variables; however, these two control variables have no significant impact on our estimation models (including the goodness of fit). One explanation for this is its collinearity or concomitant variation. In the end, we dropped these two variables.

Finally, we modified the baseline model from theoretical and empirical works and treated it as a baseline model. Then, we introduced foreign variables as the main effect of the estimation model to form our full model:

$$
\begin{aligned}
\operatorname{CSR}_{i, t}=\beta_{0}+ & \beta_{1} \text { FOREIGN }_{i, t}+\beta_{2} \text { SIZE }_{i, t}+\beta_{3} \text { LEVERAGE }_{i, t}+\beta_{4} \text { ROA }_{i, t} \\
& +\beta_{5} \text { AUDIT }_{i, t}+\beta_{6} \text { INDUSTRY }_{i, t}+\sum_{3}^{t=1} \gamma_{3 t} \text { PERIOD }_{t}+\varepsilon_{i, t}
\end{aligned}
$$

The main independent variable is FOREIGN ${ }_{i, t}$, which is measured in six different dimensions (foreign-owned, foreign board, foreign directors, foreign commissioners, foreign CEO, and foreign chairperson). We ran and re-ran the above estimation model by changing the measurement of foreign variables. INDUSTRY is a vector of industry-specific categorical variables. Year dummies $\left(P E R I O D_{t}\right)$ were included to control for common period shocks, where $P E R I O D_{t=1}$ if firm $\mathrm{I}$ is in the year $\mathrm{t}$ and 0 otherwise. All variables are defined in Appendix A.

\subsection{Variable Measurement}

\subsubsection{Corporate Social Responsibility}

Our measurement of corporate social responsibility (CSR) followed the Global Responsibility Index (GRI). We used dichotomous values for each index; we gave a " 1 " if the company discloses the relevant information regarding the index and a " 0 " if the company does not disclose the information (Khan et al., 2013). We followed a previous study that suggests annual reports as the main source of information, such as corporate social responsibility disclosure, for shareholders [36]. Therefore, we used annual reports as the main source of information for the study [21].

\subsubsection{Key Independent Variables (Foreign Board)}

This research defines foreign boards with a comprehensive and cohesive definition. Unlike previous studies that only focus on certain controlling and monitoring entities, e.g., foreign ownership [11], foreign CEOs [14], foreign directors [21], and foreign boards [34], we cover all board entities to give a more robust conclusion. The foreign board in this research has six dimensions, namely, foreign ownership (FOROWN), foreign board (FORBOARD), foreign directors (FORDIR), foreign commissioners (FORCOM), foreign CEO (FORCEO), and foreign chairperson (FORCHAIR). The foreign board refers to the percentage of foreign nationals on the company board [37]. The foreign board is divided into foreign directors, foreign CEOs, foreign commissioners, and foreign chiefs of the board of commissioners. Foreign directors refer to the percentage of foreign directors to the total number of board members [33,34,37]. A foreign CEO is a foreign national who holds the CEO position [15]. Foreign commissioners are foreign nationals who are members of the board of commissioners or when a foreign national is the chief of the board of commissioners. The foreign CEO and foreign chief board of commissioners are dummy variables, denoted by 1 if the CEO or chief of the board of commissioners is foreign. Foreign ownership is the percentage of shares held by foreign shareholders $[23,38]$. We tabulate the results of these definitions in Appendix A. 


\subsubsection{Control Variables}

As previously mentioned, the empirical CSR literature has long explored its determinants. Thus, this research controls those standard factors to isolate the independent effect of foreign boards. The four-control variable consists of firm characteristics: firm size (SIZE), profitability (ROA), leverage (LEVERAGE), and audit firm (AUDIT). The firm size is the $\mathrm{ln}$ of total assets of the firm, and the profitability measurement uses return on assets (ROA) as earnings divided by assets. Leverage is the debt-to-equity ratio, and the audit firm is a dummy variable: 1 if the audit firm is Big Four and 0 otherwise. We also take the type of industry as another control variable.

\section{Findings}

\subsection{Descriptive Statistics}

Table 1 provides the descriptive statistics of the current study. The mean value of corporate social responsibility disclosure is $32.13 \%$, which is higher than the value of $15 \%$ reported by Setiawan et al. [3] for Indonesian banks over the sample period of 2013 to 2015. On average, this study discloses one-third of the items in the GRI index, implying that corporate social responsibility disclosure in Indonesia is still considered low.

Table 1. Summary statistics.

\begin{tabular}{lccccc}
\hline \multicolumn{7}{l}{ Panel A: Descriptive Statistics } & for Continuous Variables & & \\
\hline Variable & Min & Mean & Median & Max & Std. Dev. \\
\hline CSR & 15.44 & 32.13 & 32.35 & 45.59 & 4.97 \\
FOROWN & 0.00 & 27.20 & 7.81 & 99.66 & 32.79 \\
FORBOARD & 0.00 & 14.76 & 22.00 & 90.91 & 22.45 \\
FORDIR & 0.00 & 15.79 & 10.00 & 100.00 & 15.9 \\
FORCOM & 0.00 & 14.05 & 10.00 & 100.00 & 13.5 \\
SIZE & 18.26 & 23.54 & 22.58 & 32.01 & 3.12 \\
LEVERAGE & -166.75 & 3.14 & 0.61 & 694.86 & 36.54 \\
ROA & -41.02 & 6.90 & 5.94 & 73.00 & 9.79 \\
\hline
\end{tabular}

Panel B: Descriptive statistics for dummy variables

\begin{tabular}{lcc}
\hline Variable & 1 & 0 \\
FORCEO & $17.01 \%$ & $82.99 \%$ \\
FORCHBOC & $12.47 \%$ & $87.53 \%$ \\
AUDIT FIRM & $34.9 \%$ & $65.1 \%$
\end{tabular}

Note: The definitions of all variables are provided in Appendix A. The dependent variable is CSR. The main independent variables are foreign ownership (FOROWN), foreign board (FORBOARD), foreign directors (ForDir), foreign commissioner (ForCom), foreign CEO (FORCEO), and foreign chairperson (FORCHAIR). The control variables are firm size (SIZE), firm profitability (ROA), firm leverage (LEVERAGE), Big Four audit firm (AUDIT), and industrial type (IND). Panel B provides the descriptive statistics for the dummy variables (FORCEO and FORCOM).

The mean foreign board value in Indonesia is $14.84 \%$, implying that 0.75 out of 5 firm board members in Indonesia is a foreigner. This value is higher than the value of $4.8 \%$ reported by Garanina and Aray [21] in Russia. The proportions of foreign members of the boards of directors and commissioners were not significantly different. The average values of foreign directors and foreign commissioners are $15.79 \%$ and $14.05 \%$, respectively. Finally, Table 2 shows that the foreign nationals who hold CEO and chairperson positions on boards of commissioners are $17.01 \%$ and $12.47 \%$, respectively. 
Table 2. CSR and foreigners.

\begin{tabular}{|c|c|c|c|c|c|c|c|c|c|c|c|c|}
\hline & \multicolumn{2}{|c|}{ Owner } & \multicolumn{2}{|c|}{ BOD } & \multicolumn{2}{|c|}{ Directors } & \multicolumn{2}{|c|}{ Commissioners } & \multicolumn{2}{|c|}{ CEO } & \multicolumn{2}{|c|}{ Chairperson } \\
\hline & White & $\begin{array}{l}\text { Double- } \\
\text { Clustered }\end{array}$ & White & $\begin{array}{l}\text { Double- } \\
\text { Clustered }\end{array}$ & White & $\begin{array}{l}\text { Double- } \\
\text { Clustered }\end{array}$ & White & $\begin{array}{l}\text { Double- } \\
\text { Clustered }\end{array}$ & White & $\begin{array}{l}\text { Double- } \\
\text { Clustered }\end{array}$ & White & $\begin{array}{l}\text { Double- } \\
\text { Clustered }\end{array}$ \\
\hline FOREIGN & $\begin{array}{l}0.013^{* *} \\
(0.007)\end{array}$ & $\begin{array}{l}0.034^{* * *} \\
(0.002)\end{array}$ & $\begin{array}{l}1.660 * * \\
(0.813)\end{array}$ & $\begin{array}{l}1.244^{* * * *} \\
(0.223)\end{array}$ & $\begin{array}{l}0.295 * * * \\
(0.103)\end{array}$ & $\begin{array}{l}0.307^{* * *} \\
(0.035)\end{array}$ & $\begin{array}{l}0.306^{* * * *} \\
(0.119)\end{array}$ & $\begin{array}{l}0.382^{* * *} \\
(0.061)\end{array}$ & $\begin{array}{l}0.573^{* *} \\
(0.262)\end{array}$ & $\begin{array}{l}0.818^{* * *} \\
(0.079)\end{array}$ & $\begin{array}{l}1.975^{* * *} \\
(0.496)\end{array}$ & $\begin{array}{l}0.408^{*} \\
(0.241)\end{array}$ \\
\hline SIZE & $\begin{array}{l}0.318^{* * *} \\
(0.104)\end{array}$ & $\begin{array}{l}0.390^{* * *} \\
(0.012)\end{array}$ & $\begin{array}{l}0.321^{* * *} \\
(0.106)\end{array}$ & $\begin{array}{l}0.407^{* * *} \\
(0.011)\end{array}$ & $\begin{array}{l}0.312^{* * *} \\
(0.105)\end{array}$ & $\begin{array}{l}0.394^{* * *} \\
(0.011)\end{array}$ & $\begin{array}{l}0.314^{* * *} \\
(0.105)\end{array}$ & $\begin{array}{l}0.395^{* * *} \\
(0.013)\end{array}$ & $\begin{array}{l}0.324^{* * *} \\
(0.106)\end{array}$ & $\begin{array}{l}0.409^{* * *} \\
(0.010)\end{array}$ & $\begin{array}{l}0.305^{* * *} \\
(0.106)\end{array}$ & $\begin{array}{l}0.408^{* * * *} \\
(0.012)\end{array}$ \\
\hline LEV_DER & $\begin{array}{l}-0.002 \\
(0.001)\end{array}$ & $\begin{array}{l}-0.005 \\
(0.009)\end{array}$ & $\begin{array}{l}-0.002 \\
(0.001)\end{array}$ & $\begin{array}{l}-0.005 \\
(0.009)\end{array}$ & $\begin{array}{l}-0.002 \\
(0.001)\end{array}$ & $\begin{array}{l}-0.005 \\
(0.009)\end{array}$ & $\begin{array}{l}-0.002 \\
(0.001)\end{array}$ & $\begin{array}{l}-0.005 \\
(0.009)\end{array}$ & $\begin{array}{l}-0.002 \\
(0.001)\end{array}$ & $\begin{array}{l}-0.004 \\
(0.008)\end{array}$ & $\begin{array}{l}-0.002 \\
(0.001)\end{array}$ & $\begin{array}{l}-0.005 \\
(0.008)\end{array}$ \\
\hline ROA & $\begin{array}{l}-0.001 \\
(0.011)\end{array}$ & $\begin{array}{l}0.071^{* * *} \\
(0.012)\end{array}$ & $\begin{array}{l}0.003 \\
(0.011)\end{array}$ & $\begin{array}{l}0.093^{* * *} \\
(0.011)\end{array}$ & $\begin{array}{l}-0.001 \\
(0.011)\end{array}$ & $\begin{array}{l}0.089 * * * \\
(0.010)\end{array}$ & $\begin{array}{l}0.001 \\
(0.011)\end{array}$ & $\begin{array}{l}0.093^{* * *} \\
(0.011)\end{array}$ & $\begin{array}{l}-0.005 \\
(0.011)\end{array}$ & $\begin{array}{l}0.089^{* * *} \\
(0.011)\end{array}$ & $\begin{array}{l}0.003 \\
(0.011)\end{array}$ & $\begin{array}{l}0.096^{* * *} \\
(0.011)\end{array}$ \\
\hline AUDIT & $\begin{array}{l}0.764^{* * *} \\
(0.288)\end{array}$ & $\begin{array}{l}2.468^{* * *} \\
(0.560)\end{array}$ & $\begin{array}{l}0.750 * * * \\
(0.289)\end{array}$ & $\begin{array}{l}3.585^{* * * *} \\
(0.631)\end{array}$ & $\begin{array}{l}0.657^{* * *} \\
(0.292)\end{array}$ & $\begin{array}{l}3.165^{* * *} \\
(0.559)\end{array}$ & $\begin{array}{l}0.730 * * * \\
(0.288)\end{array}$ & $\begin{array}{l}3.283^{* * *} \\
(0.652)\end{array}$ & $\begin{array}{l}0.781 \text { **** } \\
(0.287)\end{array}$ & $\begin{array}{l}3.280 * * * \\
(0.548)\end{array}$ & $\begin{array}{l}0.717^{* * * *} \\
(0.284)\end{array}$ & $\begin{array}{l}3.317^{* * * *} \\
(0.571)\end{array}$ \\
\hline IND & $\begin{array}{l}0.699 * \\
(0.381)\end{array}$ & $\begin{array}{l}0.864^{* * *} \\
(0.070)\end{array}$ & $\begin{array}{l}0.702 * \\
(0.387)\end{array}$ & $\begin{array}{l}0.844^{* * * *} \\
(0.062)\end{array}$ & $\begin{array}{l}0.692 * \\
(0.385)\end{array}$ & $\begin{array}{l}0.841^{* * * *} \\
(0.062)\end{array}$ & $\begin{array}{l}0.700 * \\
(0.385)\end{array}$ & $\begin{array}{l}0.851^{* * *} \\
(0.061)\end{array}$ & $\begin{array}{l}0.687^{*} \\
(0.386)\end{array}$ & $\begin{array}{l}0.834^{* * *} \\
(0.057)\end{array}$ & $\begin{array}{l}0.677^{*} \\
(0.386)\end{array}$ & $\begin{array}{l}0.826^{* * * *} \\
(0.060)\end{array}$ \\
\hline CONSTANT & $\begin{array}{l}22.815^{\text {**** }} \\
(2.635)\end{array}$ & $\begin{array}{l}19.692^{* * *} \\
(0.408)\end{array}$ & $\begin{array}{l}22.831^{\text {**** }} \\
(2.673)\end{array}$ & $\begin{array}{l}19.935^{* * *} \\
(0.382)\end{array}$ & $\begin{array}{l}23.063^{* * * *} \\
(2.659)\end{array}$ & $\begin{array}{l}20.193 \text { *** } \\
(0.378)\end{array}$ & $\begin{array}{l}23.048^{* * *} \\
(2.660)\end{array}$ & $\begin{array}{l}20.128^{* * *} \\
(0.374)\end{array}$ & $\begin{array}{l}22.990^{* * *} \\
(2.670)\end{array}$ & $\begin{array}{l}19.997^{* * * *} \\
(0.338)\end{array}$ & $\begin{array}{l}23.234^{* * *} \\
(2.666)\end{array}$ & $\begin{array}{l}20.069^{* * *} \\
(0.364)\end{array}$ \\
\hline $\mathrm{N}$ & 495 & 495 & 495 & 495 & 495 & 495 & 495 & 495 & 495 & 495 & 495 & 495 \\
\hline $\mathrm{R} 2$ & 0.122 & 0.162 & 0.0831 & 0.117 & 0.0922 & 0.124 & 0.0898 & 0.125 & 0.0809 & 0.118 & 0.059 & 0.115 \\
\hline
\end{tabular}

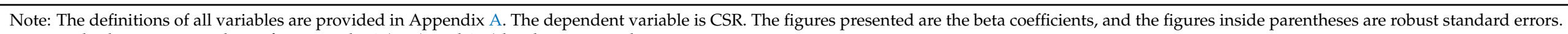

***,**, and ${ }^{*}$ denote statistical significance at the $1 \%, 5 \%$, and $10 \%$ levels, respectively. 
Tables 1 and 2 also provide information regarding the control variables. The average value of the ROA was $7.5742 \%$, with a median value of $7 \%$. On average, the firms in the sample of the study earn a positive profit. Furthermore, the mean value of leverage is $99.2676 \%$. The ratio of debt to equity in the current study is almost equal to $1-$ most of the companies in the sample of the study are audited by non-Big Four. Non-Big Four firms conducted $65.0794 \%$ of the audits and Big Four firms conducted $34.9206 \%$ of the audits.

\subsection{Regression Results}

This section provides the multivariate results using robust panel regressions. It follows the recommendation of [39] to accommodate the possible existence of a withincluster correlation by estimating all regressions using the White heteroscedastic-robust and double-clustered fixed-effect model. We performed a series of diagnostic tests prior to the estimations, including the Breusch Pagan LM test, Chow test, Hausman test, normality test, VIF of multicollinearity, autocorrelation, and heteroscedasticity. Table 2 presents the results.

In Hypothesis 1, we assume a positive relationship between foreign ownership and CSR. The result reveals a confirmation of that hypothesis $(\beta=0.013 \mathrm{SE}=0.007)$. This suggests that more ownership by foreigners in a company leads to higher CSR activities. Foreign ownership provides firms with more incentive to improve their corporate governance practices [22] by engaging more CSR. Foreign owners use their discretion to push management to pay more attention to corporate social responsibility and improve the company's involvement in corporate socially responsibility activities. Therefore, foreign ownership has a positive effect on corporate social responsibility.

The second hypothesis testing ( $\mathrm{H} 2$ : a positive relationship between the foreign board and CSR) reveals a positive relationship between a foreign board and CSR $(\beta=1.660$ $\mathrm{SE}=0.813$ ). This implies that firms with more foreigners on the board receive higher CSR than those with few foreigners on the board. Practically, an increase in foreigners on the board leads to an increase of $1.660 \%$ of the company's CSR. This is in line with prior empirical findings, which surmise the positive effect in Russia [21], Bangladesh [33], Jordan [32], and France [13].

In terms of the number of foreign directors, our result supports the existence a positive relationship between foreign directors and CSR (H3). Our research shows that foreign directors have a positive relationship with CSR $(\beta=0.295 \mathrm{SE}=0.103)$, implying that a company with more foreigners will have a higher CSR. As part of the top management team, foreign directors have the discretion to make strategic decisions regarding corporate social responsibility. Oxelheim and Randøy (2003) point out that foreign directors bring their expertise to improve firm value. Thus, foreign directors also have the discretion to push companies to be more involved in corporate social responsibility.

Foreign commissioners (H4) also positively affect CSR $(\beta=0.316 \mathrm{SE}=0.103)$, implying that more foreign commissioners on the board lead to more CSSR activities. Foreign commissioners have a monitoring responsibility to push management to pay more attention to CSR activities. The foreign commissioners, acting in a supervisory role, have a positive effect on CSR performance. Foreign commissioners use their expertise to provide better control and monitoring of CSR. This result is in line with those of previous studies that found positive effects of foreign nationals on company boards [13,32,33].

We further examined this foreign variable by evaluating the foreign CEO effect (H5). Table 2 reveals a positive relationship between foreign CEOs and CSR, confirming our hypothesis $(\beta=0.573, \mathrm{SE}=0.262)$. This implies that the CSR of a company with a foreign CEO outperforms another firm that does not have a foreign CEO, which is in alignment with the findings of previous studies such as Al-Shammari, Rasheed, and Al-Shammari [40] and Bertrand et al. [14].

Additionally, our final hypothesis test also presented a positive relationship between the foreign chairperson and CSR $(\beta=1.975 \mathrm{SE}=0.496)$. This indicates there is a significant difference in CSR activities between companies with and without a foreign chairperson. The CSR activities companies with a foreign chairperson outperform those of compa- 
nies without a foreign chairperson, which is consistent with the previous research of Bertrand et al. [14].

In sum, our result confirms that foreign involvement has a positive effect on corporate social responsibility performance. We checked the aspects of foreign ownership and foreign boards. The results of our study provide empirical evidence on the effectiveness of foreign ownership and foreign boards to improve corporate social responsibility performance. Foreign ownership forces management to be more involved in corporate social responsibility activity. This result supports the agency theory that foreign ownership is a corporate governance mechanism that brings more information, which is presented in the corporate social responsibility disclosure from the company to the shareholder. Our study also supports the important role of the foreign board members in improving corporate social responsibility. Foreign board members bring their experience and expertise to the board's capability. Therefore, foreign boards positively affect CSR disclosure. Additional evaluation through the variables of foreign CEOs, foreign chair people of the board of commissioners, foreign directors, and foreign commissioners confirm the expectation that foreign boards lead to higher CSR.

\subsection{Robustness Check: Endogeneity}

We acknowledge the potential endogeneity concern in this study. For example, some unobservable omitted firm-specific characteristics can simultaneously affect the CSR decision and foreign board composition. CSR activities may also have unobservable constructs even though we follow the empirical procedure from previous research, such as Garanina and Aray [21]. We performed a robustness check to tackle this issue, and the results are presented in Table 3.

First, we re-estimated our model specification using one-year lagging explanatory variables instead of taking their contemporaneous values [41]. This procedure can tackle the simultaneity issue of endogeneity. The results are shown in Columns (1), (3), (5), (7), (9), and (11) for each independent variable. The hypothesis testing from those columns shows that our main conclusion on the relationship between the foreign variables (foreign-owned, foreign board, foreign directors, foreign commissioner, foreign $\mathrm{CEO}$, and foreign $\mathrm{CEO}$ ) and CSR remains intact.

Additionally, we follow Williams and Allison [42] and conduct MLE-SEM to tackle the issue of simultaneity and unobserved measurement errors. The MLE-SEM method is substantially more efficient than the GMM method when the normality assumption is met, the condition of strongly balanced is achieved, and it suffers less from finite sample biases. This approach is also suitable for our sample frame due to short period observations.

Columns (2), (4), (6), (8), (10), and (12) of Table 3 reveal the MLE-SEM results. These show that all regressors have a positive relationship with the CSR, confirming our earlier findings. In other words, if the company has higher foreign-owned, foreign boards, foreign directors, and foreign commissioner characteristics, the CSR increases. It also shows that a company with a foreign CEO or foreign chairperson has higher CSR than those without foreigners. 
Table 3. Robustness checks on endogeneity.

\begin{tabular}{|c|c|c|c|c|c|c|c|c|c|c|c|c|}
\hline & \multicolumn{2}{|c|}{ Owner } & \multicolumn{2}{|c|}{ BOD } & \multicolumn{2}{|c|}{ Directors } & \multicolumn{2}{|c|}{ Commissioners } & \multicolumn{2}{|c|}{ CEO } & \multicolumn{2}{|c|}{ Chairperson } \\
\hline & $\begin{array}{l}\text { One- } \\
\text { Lagged }\end{array}$ & SEM & $\begin{array}{l}\text { One- } \\
\text { Lagged }\end{array}$ & SEM & $\begin{array}{l}\text { One- } \\
\text { Lagged }\end{array}$ & SEM & $\begin{array}{l}\text { One- } \\
\text { Lagged }\end{array}$ & SEM & $\begin{array}{l}\text { One- } \\
\text { Lagged }\end{array}$ & SEM & $\begin{array}{l}\text { One- } \\
\text { Lagged }\end{array}$ & SEM \\
\hline FOREIGN & $\begin{array}{l}0.017^{* * * *} \\
(0.003)\end{array}$ & $\begin{array}{l}0.035^{* * *} \\
(0.006)\end{array}$ & $\begin{array}{l}0.022^{* * *} \\
(0.006)\end{array}$ & $\begin{array}{l}-0.022 \text { ** } \\
(0.010)\end{array}$ & $\begin{array}{l}0.053^{* *} \\
(0.022)\end{array}$ & $\begin{array}{l}0.307^{* *} \\
(0.135)\end{array}$ & $\begin{array}{l}0.218^{* * * *} \\
(0.082)\end{array}$ & $\begin{array}{l}0.381 \text { ** } \\
(0.158)\end{array}$ & $\begin{array}{l}0.739 * * \\
(0.291)\end{array}$ & $\begin{array}{l}0.725^{* *} \\
(0.301)\end{array}$ & $\begin{array}{l}1.401 * * * \\
(0.272)\end{array}$ & $\begin{array}{l}1.070 * \\
(0.643)\end{array}$ \\
\hline SIZE & $\begin{array}{l}0.358^{* * * *} \\
(0.009)\end{array}$ & $\begin{array}{l}0.388^{* * *} \\
(0.067)\end{array}$ & $\begin{array}{l}0.347^{* * * *} \\
(0.010)\end{array}$ & $\begin{array}{l}0.405^{* * *} \\
(0.069)\end{array}$ & $\begin{array}{l}0.355^{* * *} \\
(0.010)\end{array}$ & $\begin{array}{l}0.391^{* * *} \\
(0.069)\end{array}$ & $\begin{array}{l}0.356^{* * *} \\
(0.010)\end{array}$ & $\begin{array}{l}0.393^{* * *} \\
(0.069)\end{array}$ & $\begin{array}{l}0.352^{* * * *} \\
(0.010)\end{array}$ & $\begin{array}{l}0.406^{* * *} \\
(0.069)\end{array}$ & $\begin{array}{l}0.357^{* * * *} \\
(0.010)\end{array}$ & $\begin{array}{l}0.406^{* * *} \\
(0.069)\end{array}$ \\
\hline LEVERAGE & $\begin{array}{l}0.004 \\
(0.004)\end{array}$ & $\begin{array}{l}-0.005 \\
(0.006)\end{array}$ & $\begin{array}{l}0.003 \\
(0.004)\end{array}$ & $\begin{array}{l}-0.005 \\
(0.006)\end{array}$ & $\begin{array}{l}0.004 \\
(0.004)\end{array}$ & $\begin{array}{l}-0.005 \\
(0.006)\end{array}$ & $\begin{array}{l}0.004 \\
(0.004)\end{array}$ & $\begin{array}{l}-0.005 \\
(0.006)\end{array}$ & $\begin{array}{l}0.004 \\
(0.004)\end{array}$ & $\begin{array}{l}-0.004 \\
(0.006)\end{array}$ & $\begin{array}{l}0.004 \\
(0.004)\end{array}$ & $\begin{array}{l}-0.005 \\
(0.006)\end{array}$ \\
\hline $\mathrm{ROA}$ & $\begin{array}{l}0.062^{* * *} \\
(0.011)\end{array}$ & $\begin{array}{l}0.070^{* * *} \\
(0.022)\end{array}$ & $\begin{array}{l}0.064^{* * *} \\
(0.009)\end{array}$ & $\begin{array}{l}0.092^{* * *} \\
(0.022)\end{array}$ & $\begin{array}{l}0.067^{* * *} \\
(0.010)\end{array}$ & $\begin{array}{l}0.088^{* * *} \\
(0.022)\end{array}$ & $\begin{array}{l}0.064^{* * * *} \\
(0.009)\end{array}$ & $\begin{array}{l}0.092 \text { *** } \\
(0.022)\end{array}$ & $\begin{array}{l}0.070^{* * *} \\
(0.011)\end{array}$ & $\begin{array}{l}0.088^{* * *} \\
(0.023)\end{array}$ & $\begin{array}{l}0.065^{* * *} \\
(0.010)\end{array}$ & $\begin{array}{l}0.095^{* * *} \\
(0.022)\end{array}$ \\
\hline AUDIT & $\begin{array}{l}2.632 * * * \\
(0.119)\end{array}$ & $\begin{array}{l}2.468^{* * *} \\
(0.506)\end{array}$ & $\begin{array}{l}3.741^{* * *} \\
(0.292)\end{array}$ & $\begin{array}{l}3.585^{* * *} \\
(0.506)\end{array}$ & $\begin{array}{l}3.290^{* * *} \\
(0.213)\end{array}$ & $\begin{array}{l}3.165^{* * * *} \\
(0.491)\end{array}$ & $\begin{array}{l}3.528^{* * * *} \\
(0.259)\end{array}$ & $\begin{array}{l}3.263^{* * * *} \\
(0.508)\end{array}$ & $\begin{array}{l}3.433^{* * *} \\
(0.250)\end{array}$ & $\begin{array}{l}3.280 * * * \\
(0.481)\end{array}$ & $\begin{array}{l}3.562 * * * \\
(0.243)\end{array}$ & $\begin{array}{l}3.317^{* * *} \\
(0.471)\end{array}$ \\
\hline IND & $\begin{array}{l}1.035^{* * *} \\
(0.112)\end{array}$ & $\begin{array}{l}0.954 * * * \\
(0.230)\end{array}$ & $\begin{array}{l}1.030^{* * *} \\
(0.109)\end{array}$ & $\begin{array}{l}0.948^{* * *} \\
(0.231)\end{array}$ & $\begin{array}{l}1.041^{* * *} \\
(0.107)\end{array}$ & $\begin{array}{l}0.960^{* * * *} \\
(0.232)\end{array}$ & $\begin{array}{l}1.043^{* * *} \\
(0.106)\end{array}$ & $\begin{array}{l}0.959 * * * \\
(0.232)\end{array}$ & $\begin{array}{l}1.050^{* * *} \\
(0.107)\end{array}$ & $\begin{array}{l}0.961 * * * \\
(0.231)\end{array}$ & $\begin{array}{l}1.053^{* * *} \\
(0.105)\end{array}$ & $\begin{array}{l}0.967^{* * *} \\
(0.231)\end{array}$ \\
\hline CONSTANT & $\begin{array}{l}19.835^{* * * *} \\
(0.408)\end{array}$ & $\begin{array}{l}20.506^{* * *} \\
(1.665)\end{array}$ & $\begin{array}{l}20.518^{* * * *} \\
(0.464)\end{array}$ & $\begin{array}{l}21.175^{* * *} \\
(1.668)\end{array}$ & $\begin{array}{l}20.151^{* * *} \\
(0.407)\end{array}$ & $\begin{array}{l}20.833^{* * * *} \\
(1.669)\end{array}$ & $\begin{array}{l}20.186^{* * *} \\
(0.439)\end{array}$ & $\begin{array}{l}20.862^{* * * *} \\
(1.668)\end{array}$ & $\begin{array}{l}20.221 \text { *** } \\
(0.447)\end{array}$ & $\begin{array}{l}20.940^{* * *} \\
(1.669)\end{array}$ & $\begin{array}{l}20.137^{* * *} \\
(0.448)\end{array}$ & $\begin{array}{l}20.846^{* * *} \\
(1.664)\end{array}$ \\
\hline
\end{tabular}

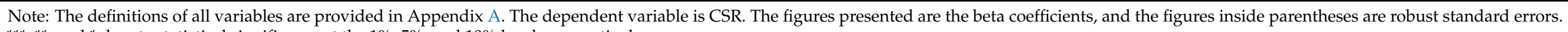
***,**, and $*$ denote statistical significance at the $1 \%, 5 \%$, and $10 \%$ levels, respectively. 


\subsection{Robustness Check: Alternative Measurements}

This research measures the "foreignness" by taking the fraction of directors on the board. However, another widely considered approach in the literature is the presence or absence of such board members, as suggested by Stroup [43] and Masulis et al. [44]. Given that the existence of any foreign director on the board may affect the CSR activities, we consider taking a binary approach in measuring the "foreignness." We use a dummy variable, in which we give a score " 1 " if there is a presence of international board members, and otherwise " 0 ".

We re-estimate the model using this binary variable, and the results are presented in Table 4 . The findings show that firms with the presence of international board members, either on the board, as directors, or as commissioners, have better CSR activities than firms with the absence of international board members. This lends further credence to our earlier results that their relationships are positive. The consistent results across the four newly constructed independent variables (owners, board members, directors, and commissioners) suggest that foreignness may result in superior CSR activities.

Table 4. Robustness checks for alternative measurements.

\begin{tabular}{lllll}
\hline & \multicolumn{1}{c}{ Owner } & \multicolumn{1}{c}{ BOD } & \multicolumn{1}{c}{ Directors } & \multicolumn{1}{c}{ Commissioners } \\
\hline FOREIGN & $1.568^{* *}$ & $0.466^{*}$ & $0.857^{* * *}$ & $1.029^{* *}$ \\
& $(0.753)$ & $(0.254)$ & $(0.262)$ & $(0.438)$ \\
SIZE & $0.333^{* * *}$ & $0.320^{* * *}$ & $0.329^{* * *}$ & $0.321^{* * *}$ \\
& $(0.091)$ & $(0.103)$ & $(0.103)$ & $(0.103)$ \\
LEV_DER & -0.004 & $-0.002^{* *}$ & $-0.002^{*}$ & $-0.002^{*}$ \\
& $(0.013)$ & $(0.001)$ & $(0.001)$ & $(0.001)$ \\
ROA & $0.059^{* * *}$ & -0.003 & -0.003 & -0.002 \\
& $(0.021)$ & $(0.011)$ & $(0.011)$ & $(0.011)$ \\
AUDIT & $2.742^{* * *}$ & $0.813^{* * *}$ & $0.743^{* * *}$ & $0.743^{* * *}$ \\
& $(0.544)$ & $(0.287)$ & $(0.285)$ & $(0.288)$ \\
IND & $1.044^{* * *}$ & $0.754^{* *}$ & $0.775^{* *}$ & $0.723^{*}$ \\
& $(0.347)$ & $(0.376)$ & $(0.375)$ & $(0.375)$ \\
CONSTANT & $19.513^{* * *}$ & $22.539^{* * *}$ & $22.205^{* * *}$ & $22.647^{* * *}$ \\
& $(2.518)$ & $(2.605)$ & $(2.599)$ & $(2.599)$ \\
\hline N & 495 & 495 & 495 & 495
\end{tabular}

Note: The dependent variable is CSR. To conserve space, we summarize all estimation results in one table. ${ }^{* * *},{ }^{* *}$ and * denote statistical significance at the $1 \%, 5 \%$, and $10 \%$ levels, respectively.

\subsection{Robustness Check: Industrial Effect}

Our research consists of nonfinancial firms from a large number of industries. Thus, the earlier findings might be the net effect of varying relationships across industries offsetting each other. Hence, we re-estimated our model specification for each industry as a robustness check.

We classified each industry into three categories based on the nature of business and the number of observations. The manufacturing and basic industries dominate our sample. Other firms, such as mining and trading, are classified as one miscellaneous industry. Note that the results shown in Table 5 are not from three estimations. Rather, they are from 18 different estimation models. For brevity reasons, we do not show all the variables (control variables and intercepts). Instead, we summarize the results from the main independent variables and put them in one table. Table 5 reveals the results of the within-industry results. 
Table 5. Robustness checks for industrial subsampling.

\begin{tabular}{llll}
\hline & \multicolumn{1}{c}{ Manufacturing } & \multicolumn{1}{c}{ Basic Industry } & \multicolumn{1}{c}{ Others } \\
\hline Foreign Owned & $0.013^{* * *}$ & $0.026^{* * *}$ & $0.019^{* * *}$ \\
& $(0.004)$ & $(0.004)$ & $(0.004)$ \\
Foreign Board & $0.025^{* * *}$ & $3.855^{* *}$ & $1.910^{* *}$ \\
& $(0.005)$ & $(1.546)$ & $(0.940)$ \\
Foreign Directors & $0.207^{* * *}$ & $0.426^{* *}$ & -0.151 \\
& $(0.070)$ & $(0.194)$ & $(0.103)$ \\
Foreign & & & \\
Commissioner & 0.089 & $0.440^{*}$ & 0.119 \\
Foreign CEO & $(0.124)$ & $(0.255)$ & $(0.148)$ \\
& $1.255^{* *}$ & $3.490^{* * *}$ & $0.597^{* *}$ \\
Foreign Chairperson & $(0.503)$ & $(0.830)$ & $(0.300)$ \\
& $2.544^{* * *}$ & $1.808^{* *}$ & -0.263 \\
& $(0.340)$ & $(0.874)$ & $(0.453)$ \\
\hline
\end{tabular}

Note: The dependent variable is CSR. To conserve space, we summarize all estimation results in one table. ${ }^{* * *}{ }^{* *}$ and ${ }^{*}$ denote statistical significance at the $1 \%, 5 \%$, and $10 \%$ levels, respectively.

As expected, the conclusions for each group vary. For the manufacturing industry, all foreign variables have positive effects on CSR, except for foreign commissioners. This implies that the number of foreign commissioners on the board is not significant for CSR activities. Meanwhile, the basic industry results align with our main findings: all foreign variables positively impact CSR. Last, the other industries have interesting results. Only foreign-owned, foreign boards, and foreign CEOs have a positive relationship with CSR. The other foreign variables, such as foreign directors, foreign commissioners, and foreign chairpersons, are not a key factor for CSR.

\subsection{Discussion}

Our results suggest that foreign ownership and foreign boards have a positive effect on CSR performance. This finding confirms the expectation that foreign ownership will positively impact the company's decision to be more involved in CSR activities. This result is in line with previous studies, such as Rustam et al. [13], Hu and Zhu [26], and Khan et al. [12]. The positive effect of foreign ownership empirically proves the agency theory. The agency theory predicts information asymmetry between management and stakeholders because management has more access to inside information than stakeholders. Thus, it is important to reduce the level of information asymmetry through greater disclosure. As part of the shareholders, foreign owners can use their discretion to push management to further disclose corporate social responsibility and be more actively involved in corporate social responsibility activities. Foreign owners prefer to maintain their reputations through more corporate social responsibility activities. Foreign ownership will thus improve the corporate social responsibility of the company.

Our results also support the legitimacy theory in corporate social responsibility activity. Foreign owners apply more pressure than other shareholders to perform well. Foreign ownership is perceived as the better institution to apply corporate social responsibility mechanisms. As Deegan [45] and Islam [46] pointed out, a company will react to external pressure. In this case, foreign ownership brings more experience as a global company. Thus, it is expected that the company will absorb the best practices from other countries. Foreign owners use their discretion to achieve better corporate social responsibility. Our result confirms previous studies $[12,13,26]$ that foreign ownership improves CSR performance.

Our results also provide evidence regarding the important role of the foreign board members in CSR performance. Foreign board members have incentives to prove themselves capable board members. They will maintain their reputation as foreign nationals who hold board member positions. In line with the agency theory perspective, foreign board members, as part of corporate governance mechanisms, use their discretion to monitor management with respect to corporate social responsibility activities. 
Moreover, our study provides further evidence concerning the board of commissioners and directors, because Indonesia uses the two-tier board system. In Indonesian companies, the board of commissioners functions as a supervisory board, and the board of directors has to manage the company operations. First, our study checks the role of foreign nationals in the top position on both boards. With a foreign CEO, shareholders pay more attention to firm performance. Foreign CEOs are expected to deliver higher performance and more compliance with social responsibility. Foreign CEOs need to gain legitimacy from society and shareholders. Thus, foreign CEOs boost firm performance through corporate social responsibility. Foreign CEOs have improved CSR performance. Our result is in line with the previous study of Bertrand et al. [14], who found that foreign CEOs positively affect corporate social responsibility using cross-country data. A firm with a foreign CEO outperforms a firm without a foreign CEO.

Furthermore, our study checks the effect of a foreign chairperson of the board of commissioners on corporate social responsibility. As the chairperson of the supervisory board, a foreign chairperson is responsible for maintaining the firm reputation, and yet, he or she also has a reputation to establish and uphold. Our results provide empirical evidence to support this expectation. Foreign chairpersons have improved firm CSR performance. Both foreign CEOs and foreign chairpersons use their experience and expertise to positively impact corporate social responsibility performance. They maintain their reputation to gain legitimacy. Our results also confirm the expectation that foreign CEOs and foreign chairpersons have improved CSR disclosure [14] and reduced information asymmetry.

Our study also checks the effect of foreign commissioners and foreign directors on corporate social responsibility. Foreign commissioners as part of the supervisory board have a responsibility to monitor the management team. It is expected that foreign commissioners bring more expertise to accelerate the company to adopt the best practices in corporate social responsibility. As suggested by the legitimacy theory, foreign commissioners respond to expectations from shareholders to improve CSR performance. Our result confirms the expectation that foreign commissioners have a positive impact on CSR performance. Thus, our study is in line with those of previous studies that found positive impacts of foreign directors on CSR $[13,21,32,33]$.

Furthermore, our study also checked how foreign nationality directors affect CSR performance. Foreign directors, as part of the board of directors, have a responsibility to manage firm operations. Thus, foreign directors should respond to shareholder expectations regarding CSR activity. A foreign director is expected to have more knowledge and information regarding the best CSR practices of other countries. Foreign directors transmit this knowledge to their companies $[16,17,30]$.

As an additional note, legitimacy theory argues that CSR activities might be influenced by firm characteristics such as size, profitability, and leverage [47]. Smaller firms (or lower profitability) will have a lower CSR activity from larger (or higher profitability) firms, which was revealed in our earlier findings (see Table 2). Therefore, one intriguing question remains: would these firm characteristics strengthen/weaken the international board members' effects on CSR? We re-estimated all the possibilities following Brambor et al.'s [48] procedure although it violated the moderation criterion and was beyond our main research objectives. Note that Dawson [49] and Balli and Sorensen [50] argue that introducing an interaction term needs to fulfill the theoretical requirement: mixed findings. However, the literature in this area has a consensus: firm characteristics and board members are critical factors in increasing CSR activities [47].

Nevertheless, we still re-estimated and found that the interactions between each international board member constructs (BOD, directors, commissioners, $\mathrm{CEO}$, and chairperson) and the firm characteristics have no significant relationship with CSR activities. It implies that the international board members' effect on CSR activities is not due to their firm characteristics. The presence of international board members has a positive relationship with CSR no matter the size of the firms. It also implies that larger firms have higher 
CSR activities regardless of whether they have international board members or not. The descriptive statistics in Table 6 strengthen our arguments.

Table 6. Crosstab across firm characteristics and international board members.

\begin{tabular}{lccc}
\hline Panel A. Firm Characteristics & & & \\
\hline Variable & $\mathrm{Q} 1$ & $\mathrm{Q} 1-\mathrm{Q} 3$ & $\mathrm{Q} 3$ \\
\hline Size & 30.38 & 31.99 & 33.08 \\
Profitability & 31.1 & 32.03 & 33.04 \\
Leverage & 31.66 & 32.41 & 32.21 \\
\hline Panel B. Size & & & $\mathrm{Q3}$ \\
\hline Variable & $\mathrm{Q} 1$ & $\mathrm{Q} 1-\mathrm{Q} 3$ & 32.81 \\
\hline BOD & 31.57 & 32.67 & 33.02 \\
Dir & 31.55 & 33.55 & 32.7 \\
Com & 31.91 & 32.48 & $\mathrm{Q3}$ \\
\hline Panel C. Profitability & & & 33.7 \\
\hline Variable & $\mathrm{Q} 1$ & $\mathrm{Q} 1-\mathrm{Q} 3$ & 35.44 \\
\hline BOD & 31.6 & 31.89 & 33.05 \\
DIR & 31.52 & 33.44 & $\mathrm{Q3}$ \\
COM & 31.8 & 32.5 & 32.89 \\
\hline Panel D. Leverage & & & 31.07 \\
\hline Variable & $\mathrm{Q} 1$ & $\mathrm{Q} 1-\mathrm{Q} 3$ & 32.56 \\
\hline BOD & 31.96 & 31.35 & \\
DIR & 31.84 & 28.76 & \\
COM & 32.16 & & \\
\hline NO: & & & \\
\hline
\end{tabular}

Note: The reported values are CSR values. Panel B reports the CSR values for international board members in each quartile of size. Panel C reports the CSR values for international board members in each quartile of profitability. Panel D reports the CSR values for international board members in each quartile of leverage. Q1, Q1-Q3, and Q3 refer to first quartile, interquartile, and third quartile of CSR values, respectively.

\section{Conclusions}

This research examined the effect of foreign boards on corporate social responsibility performance. Using Indonesia as the research subject, the result confirms the expectation that foreign boards improve corporate social responsibility, supporting legitimacy theory. This implies the key role of foreigners in control and monitoring, especially in strategic choices such as CSR. The findings lay the foundations for further research in CSR literature, especially in the emerging market context. Our study also provides evidence that foreign ownership has improve the corporate social responsibility. Foreign ownership leads to higher corporate social responsibility.

Addressing the issue of foreigners' role in CSR has been our focus. To do so, we captured foreigners in more comprehensive measurements by considering all managerial involvement of foreigners in corporations. This finding implies that corporate governance mechanisms, through the identity of the board, do matter for CSR, which suggests that having an international board member is not a bad idea, especially if the firms intend to increase their CSR activities. In sum, this finding suggests that more diversified board membership is positive for corporate governance mechanisms in light of firm legitimacy through CSR.

While we offer a new perspective regarding the role of foreign boards in CSR, our study does have limitations. First, we did not directly measure the international exposure and experience of the board members. For instance, local board members might have the same level of rigorousness in CSR if they have experience as board members abroad. This study also does not take into account the country of origin of the foreigners on a board. The national culture of foreigners may have an impact on CSR activities. This study also 
does not consider the cross-listing aspect of the firm. Because those issues lay on different theoretical and conceptual gaps, they can be other interesting extensions of this analysis.

Author Contributions: Conceptualization, D.S., R.K.B., and A.A.; Formal analysis, D.S., R.K.B., and S.M.; Investigation, D.S., A.A., and S.M.; Methodology, D.S. and R.K.B.; Writing-original draft, D.S., R.K.B., A.A., and S.M.; Writing-review and editing, D.S. and R.K.B. All authors have read and agreed to the published version of the manuscript.

Funding: The authors acknowledge financial support from Directorate General of Higher Education, Ministry of Education, Culture, Research and Technology, Republic of Indonesia, under grant no. 221.1/UN27.22/HK.07.00/2021.

Institutional Review Board Statement: Not Applicable.

Data Availability Statement: The data presented in this study are available upon request from the corresponding author.

Conflicts of Interest: The authors declare no conflict of interest.

\section{Appendix A}

\begin{tabular}{|c|c|}
\hline Variable & Definition \\
\hline \multicolumn{2}{|l|}{ Dependent Variable } \\
\hline CSR & $\begin{array}{l}\text { Refer to GRI index. We use dichotomous values for each index; we } \\
\text { give " } 1 \text { " if the company discloses the relevant information regarding } \\
\text { the index and "0" if the company does not disclose the } \\
\text { information [12]. }\end{array}$ \\
\hline \multicolumn{2}{|l|}{ Independent Variable } \\
\hline Foreign ownership & The percentage of shares held by foreign shareholders $[21,23,38]$. \\
\hline Foreign board & The percentage of foreign nationals on the company board [37]. \\
\hline Foreign CEO & $\begin{array}{l}\text { A foreign national holds the CEO position [15]-a dummy variable; } 1 \\
\text { if the CEO is foreign and } 0 \text { otherwise. }\end{array}$ \\
\hline Foreign Chairperson & $\begin{array}{l}\text { A foreign national is chairperson of the board of } \\
\text { commissioners [15]—a dummy variable; } 1 \text { if the chairperson is } \\
\text { foreign and } 0 \text { otherwise. }\end{array}$ \\
\hline Foreign Directors & The percentage of foreign directors on a board of directors $[33,34,37]$. \\
\hline Foreign Commissioners & $\begin{array}{l}\text { The percentage of foreign commissioners on a board of } \\
\text { commissioners }[33,34,37] \text {. }\end{array}$ \\
\hline \multicolumn{2}{|l|}{ Control Variable } \\
\hline Firm size & Ln of total assets \\
\hline ROA & Return on assets \\
\hline Leverage & Debt to equity ratio \\
\hline Audit firm & Dummy variable; 1 if the audit firm is Big Four and 0 otherwise. \\
\hline
\end{tabular}

\section{References}

1. Halkos, G.; Nomikos, S. Corporate social responsibility: Trends in global reporting initiative standards. Econ. Anal. Policy 2021, 69, 106-117. [CrossRef]

2. Brooks, C.; Oikonomou, I. The effects of environmental, social and governance disclosures and performance on firm value: A review of the literature in accounting and finance. Br. Account. Rev. 2018, 50, 1-15. [CrossRef]

3. Setiawan, D.; Prabowo, R.; Arnita, V.; Wibawa, A. Does corporate social responsibility affect earnings management? Evidence from the Indonesian banking industry. Business. Theory Pract. 2019, 20, 372-378.

4. Mohmed, A.; Flynn, A.; Grey, C. The link between CSR and earnings quality: Evidence from Egypt. J. Account. Emerg. Econ. 2019, 10, 1-20. [CrossRef]

5. Kim, Y.C.; Seol, I.; Kang, Y.S. A study on the earnings response coefficient (ERC) of socially responsible firms. Manag. Res. Rev. 2018, 41, 1010-1032. [CrossRef]

6. Ylönen, M.; Laine, M. For logistical reasons only? A case study of tax planning and corporate social responsibility reporting. Crit. Perspect. Account. 2015, 33, 5-23. [CrossRef]

7. Kontesa, M.; Brahmana, R.K.; Memarista, G. Does Market Competition Motivate Corporate Social Responsibility? Insight from Malaysia. J. Ekon. Malays. 2020, 54, 167-179. 
8. Tibiletti, V.; Marchini, P.L.; Furlotti, K.; Medioli, A. Does corporate governance matter in corporate social responsibility disclosure? Evidence from Italy in the "era of sustainability". Corp. Soc. Responsib. Environ. Manag. 2021, 28, 896-907. [CrossRef]

9. Velte, P. Determinants and consequences of corporate social responsibility assurance: A systematic review of archival research. Soc. Bus. Rev. 2021, 16, 1-25. [CrossRef]

10. Agyei-Mensah, B.K. Internal control information disclosure and corporate governance: Evidence from an emerging market. Corp. Gov. Int. J. Bus. Soc. 2016, 16, 79-95. [CrossRef]

11. McGuinness, P.B.; Vieito, J.P.; Wang, M. The role of board gender and foreign ownership in the CSR performance of Chinese listed firms. J. Corp. Financ. 2017, 42, 75-99. [CrossRef]

12. Khan, A.; Muttakin, M.B.; Siddiqui, J. Corporate Governance and Corporate Social Responsibility Disclosures: Evidence from an Emerging Economy. J. Bus. Ethics 2013, 114, 207-223. [CrossRef]

13. Rustam, A.; Wang, Y.; Zameer, H. Does foreign ownership affect corporate sustainability disclosure in Pakistan? A sequential mixed methods approach. Environ. Sci. Pollut. Res. 2019, 26, 31178-31197. [CrossRef]

14. Bertrand, O.; Betschinger, M.-A.; Moschieri, C. Are firms with foreign CEOs better citizens? A study of the impact of CEO foreignness on corporate social performance. J. Int. Bus. Stud. 2021, 52, 525-543. [CrossRef]

15. Conyon, M.J.; Haß, L.H.; Vergauwe, S.; Zhang, Z. Foreign experience and CEO compensation. J. Corp. Financ. 2019, 57, 102-121. [CrossRef]

16. Oxelheim, L.; Randøy, T. The impact of foreign board membership on firm value. J. Bank. Financ. 2003, 27, 2369-2392. [CrossRef]

17. Hooghiemstra, R.; Hermes, N.; Oxelheim, L.; Randøy, T. Strangers on the board: The impact of board internationalization on earnings management of Nordic firms. Int. Bus. Rev. 2019, 28, 119-134. [CrossRef]

18. Du, X.; Jian, W.; Lai, S. Do Foreign Directors Mitigate Earnings Management? Evidence from China. Int. J. Account. 2017, 52, 142-177. [CrossRef]

19. Wen, W.; Cui, H.; Ke, Y. Directors with foreign experience and corporate tax avoidance. J. Corp. Finance 2020, 62, 101624. [CrossRef]

20. DiMaggio, P.J.; Powell, W.W. The iron cage revisited: Institutional isomorphism and collective rationality in organizational fields. Am. Sociol. Rev. 1983, 48, 147-160. [CrossRef]

21. Garanina, T.; Aray, Y. Enhancing CSR disclosure through foreign ownership, foreign board members, and cross-listing: Does it work in Russian context? Emerg. Mark. Rev. 2021, 46, 100754. [CrossRef]

22. Kim, I.J.; Eppler-Kim, J.; Kim, W.S.; Byun, S.J. Foreign investors and corporate governance in Korea. Pacific-Basin Financ. J. 2010, 18, 390-402. [CrossRef]

23. Setiawan, D.; Bandi, B.; Phua, L.K.; Trinugroho, I. Ownership structure and dividend policy in Indonesia. J. Asia Bus. Stud. 2016, 10, 230-252. [CrossRef]

24. Liu, N.; Laing, E.; Cao, Y.; Zhang, X. Institutional ownership and corporate transparency in China. Financ. Res. Lett. 2018, 24, 328-336. [CrossRef]

25. Vo, X.V.; Chu, T.K.H. Do foreign shareholders improve corporate earnings quality in emerging markets? Evidence from Vietnam. Cogent Econ. Financ. 2019, 7, 1698940. [CrossRef]

26. Hu, Y.Y.; Zhu, Y.; Tucker, J.; Hu, Y. Ownership influence and CSR disclosure in China. Account. Res. J. 2018, 31, 8-21. [CrossRef]

27. Al-Gamrh, B.; Al-Dhamari, R.; Jalan, A.; Jahanshahi, A.A. The impact of board independence and foreign ownership on financial and social performance of firms: Evidence from the UAE. J. Appl. Account. Res. 2020, 21, 201-229. [CrossRef]

28. Gulzar, M.A.; Cherian, J.; Hwang, J.; Jiang, Y.; Sial, M.S. The Impact of Board Gender Diversity and Foreign Institutional Investors on the Corporate Social Responsibility (CSR) Engagement of Chinese Listed Companies. Sustainability 2019, 11, 307. [CrossRef]

29. Mishra, A.V. Foreign Ownership and Firm Value: Evidence from Australian Firms. Asia-Pacific Financ. Mark. 2014, 21, 67-96. [CrossRef]

30. Giannetti, M.; Liao, G.; Yu, X. The Brain Gain of Corporate Boards: Evidence from China. J. Financ. 2015, 70, 1629-1682. [CrossRef]

31. Ullah, F.; Jiang, P.; Shahab, Y.; Zheng, C. Board of directors' foreign experience and stock price informativeness. Int. J. Financ. Econ. 2020, 26, 5160-5182. [CrossRef]

32. Ibrahim, A.H.; Hanefah, M.M. Board diversity and corporate social responsibility in Jordan. J. Financ. Rep. Account. 2016, 14, 279-298. [CrossRef]

33. Muttakin, M.B.; Khan, A.; Subramaniam, N. Firm characteristics, board diversity and corporate social responsibility. Pac. Account. Rev. 2015, 27, 353-372. [CrossRef]

34. Colakoglu, N.; Eryilmaz, M.; Martínez-Ferrero, J. Is board diversity an antecedent of corporate social responsibility performance in firms? A research on the 500 biggest Turkish companies. Soc. Responsib. J. 2021, 17, 243-262. [CrossRef]

35. Majeed, S.; Aziz, T.; Saleem, S. The Effect of Corporate Governance Elements on Corporate Social Responsibility (CSR) Disclosure: An Empirical Evidence from Listed Companies at KSE Pakistan. Int. J. Financ. Stud. 2015, 3, 530-556. [CrossRef]

36. Guthrie, J.; Parker, L.D. Corporate social disclosure practice: A comparative international analysis. Adv. Public Interest Account. 1990, 3, 159-175.

37. Beji, R.; Yousfi, O.; Loukil, N.; Omri, A. Board Diversity and Corporate Social Responsibility: Empirical Evidence from France. J. Bus. Ethic 2021, 173, 133-155. [CrossRef]

38. Setiawan, D.; Aryani, Y.A.; Yuniarti, S.; Brahmana, R.K. Does Ownership Structure Affect Dividend Decisions? Evidence from Indonesia's Banking Industry. Int. J. Bus. 2019, 24, 330-344. 
39. Petersen, M.A. Estimating Standard Errors in Finance Panel Data Sets: Comparing Approaches. Rev. Financ. Stud. 2008, 22, 435-480. [CrossRef]

40. Al-Shammari, M.; Rasheed, A.; Al-Shammari, H.A. CEO narcissism and corporate social responsibility: Does CEO narcissism affect CSR focus? J. Bus. Res. 2019, 104, 106-117. [CrossRef]

41. Bellemare, M.F.; Masaki, T.; Pepinsky, T.B. Lagged Explanatory Variables and the Estimation of Causal Effect. J. Political 2017, 79, 949-963. [CrossRef]

42. Williams, R.; Allison, P.D.; Moral-Benito, E. Linear Dynamic Panel-data Estimation Using Maximum Likelihood and Structural Equation Modeling. Stata J. Promot. Commun. Stat. Stata 2018, 18, 293-326. [CrossRef]

43. Stroup, C. International deal experience and cross-border acquisitions. Econ. Inq. 2017, 55, 73-97. [CrossRef]

44. Masulis, R.; Wang, C.; Xie, F. Globalizing the boardroom-The effects of foreign directors on corporate governance and firm performance. J. Account. Econ. 2012, 53, 527-554. [CrossRef]

45. Deegan, C. Introduction. Account. Audit. Account. J. 2002, 15, 282-311. [CrossRef]

46. Islam, M.A. CSR Reporting and Legitimacy Theory: Some Thoughts on Future Research Agenda. In The Dynamics of Corporate Social Responsibility: A Critical Approach to Theory and Practice; Aluchna, M., Idowu, S.O., Eds.; Springer International Publishing: Cham, Switzerland, 2017; pp. 323-339.

47. Patten, D.M. Seeking legitimacy. Sustain. Account. Manag. Policy J. 2019, 11, 1009-1021. [CrossRef]

48. Brambor, T.; Clark, W.R.; Golder, M. Understanding Interaction Models: Improving Empirical Analyses. Political Anal. 2006, 14, 63-82. [CrossRef]

49. Dawson, J.F. Moderation in Management Research: What, Why, When, and How. J. Bus. Psychol. 2014, 29, 1-19. [CrossRef]

50. Balli, H.O.; Sørensen, B.E. Interaction effects in econometrics. Empir. Econ. 2013, 45, 583-603. [CrossRef] 